\title{
Biochar alleviates metal toxicity and improves microbial community functions in a soil co-contaminated with cadmium and lead
}

\author{
Nahid Azadi ${ }^{1} \cdot$ Fayez Raiesi ${ }^{1}$ (i) \\ Received: 3 March 2021 / Accepted: 2 September 2021 / Published online: 6 October 2021 \\ (c) The Author(s) 2021
}

\begin{abstract}
Soil amendment with biochar alleviates the toxic effects of heavy metals on microbial functions in single-metal contaminated soils. Yet, it is unclear how biochar application would improve microbial activity and enzymatic activity in soils co-polluted with toxic metals. The present research aimed at determining the response of microbial and biochemical attributes to addition of sugarcane bagasse biochar (SCB) in cadmium $(\mathrm{Cd})$-lead $(\mathrm{Pb})$ co-contaminated soils. SCBs $\left(400\right.$ and $\left.600{ }^{\circ} \mathrm{C}\right)$ decreased the available concentrations of $\mathrm{Cd}$ and $\mathrm{Pb}$, increased organic carbon (OC) and dissolved organic carbon (DOC) contents in soil. The decrease of metal availability was greater with $600{ }^{\circ} \mathrm{C} \mathrm{SCB}$ than with $400{ }^{\circ} \mathrm{C} \mathrm{SCB}$, and metal immobilization was greater for $\mathrm{Cd}(16 \%)$ than for $\mathrm{Pb}(12 \%)$ in co-spiked soils amended with low-temperature $\mathrm{SCB}$. Biochar application improved microbial activity and biomass, and enzymatic activity in the soils co-spiked with metals, but these positive impacts of SCB were less pronounced in the co-spiked soils than in the single-spiked soils. SCB decreased the adverse impacts of heavy metals on soil properties largely through the enhanced labile $\mathrm{C}$ for microbial assimilation and partly through the immobilization of metals. Redundancy analysis further confirmed that soil OC was overwhelmingly the dominant driver of changes in the properties and quality of contaminated soils amended with SCB. The promotion of soil microbial quality by the lowtemperature SCB was greater than by high-temperature SCB, due to its higher labile C fraction. Our findings showed that SCB at lower temperatures could be applied to metal co-polluted soils to mitigate the combined effects of metal stresses on microbial and biochemical functions.
\end{abstract}

Keywords Bagasse biochar $\cdot$ Microbial activity $\cdot$ Soil enzymes $\cdot$ Metal co-contamination

\section{Introduction}

Soil contamination with cadmium $(\mathrm{Cd})$ and lead $(\mathrm{Pb})$ is an important environmental concern because of their high toxicity and non-biodegradable nature, as well as different source contributions in the soil-plant system (Alloway 2013; Smolders and Mertens 2013; Steinnes et al. 2013; Wang et al. 2020). These highly mobile and potentially toxic elements enter into soils mainly through anthropogenic activities such as metal-mining/smelting activities and land application of sewage sludge (Alloway 2013; Palansooriya et al.

Nahid Azadi

nahidazadi93@gmail.com

Fayez Raiesi

f_raiesi@yahoo.com

1 Faculty of Agriculture, Department of Soil Science and Engineering, Shahrekord University, P.O. Box 115, Shahrekord, Iran
2020). Cadmium and $\mathrm{Pb}$ are those soil toxic metals that mostly exist together in contaminated areas due to their identical anthropogenic and natural sources, particularly through wastes produced during ore mining and industrial activities (Alloway 2013; Palansooriya et al. 2020). Therefore, it is anticipated that the potential toxicity of these metals would concomitantly affect soil microbial community and properties at metal-contaminated sites (Xu et al. 2018, 2019; Ni et al. 2019; Jiang et al. 2020). Numerous earlier studies have demonstrated a detrimental influence of $\mathrm{Cd}$ and $\mathrm{Pb}$, both singly and jointly, on microbial and biochemical properties/ processes, often with reduced microbial activity, microbial biomass and enzyme activity in polluted soils (Khan et al. 2010; Huang et al. 2017; Zhan et al. 2018; Nie et al. 2018; Xu et al. 2018, 2019). Metal co-contamination has a greater negative effect on soil microbial community and enzyme activity compared with single metals (Huang et al. 2017; Zhan et al. 2018; Xu et al. 2019). For example, it was reported that the co-contamination of $\mathrm{Cd}$ and $\mathrm{Pb}$ inhibited 
the activity and biomass of the soil microbial community as well as soil enzymatic activities more than soil contamination with single $\mathrm{Cd}$ or $\mathrm{Pb}$ (Khan et al. 2010; Zhan et al. 2018; $\mathrm{Xu}$ et al. 2018, 2019). However, responses of soil microbial communities and biogeochemical processes to metal contamination, alone or in combination, depend upon soil conditions and environmental factors (Vig et al. 2003; Abdu et al. 2017), which play a crucial role in the solubility and toxicity potential of metals (Bolan et al. 2014; Shaheen et al. 2019; Palansooriya et al. 2020). Amongst soil factors, $\mathrm{pH}$ and the content of soil organic matter (SOM) are important determinants of metal mobility and availability (Smolders and Mertens 2013; Bolan et al. 2014; Palansooriya et al. 2020), because of their impacts on metal adsorption, precipitation, surface complexation, ion exchange, their speciation in the soil solution and fractionation within the soil solid phases (Bolan et al. 2014; Palansooriya et al. 2020). Soil properties and processes, particularly $\mathrm{pH}$ and SOM, are known to improve with application of biochar (Spokas et al. 2010; Lehmann et al. 2011; Gul et al. 2015; Khadem and Raiesi 2017; Zhang et al. 2018; Song et al. 2019), a carbon-rich amendment produced during the pyrolysis of biomass under oxygen-limited conditions (Lehmann et al. 2011; Mukherjee et al. 2011). However, the direction and magnitude of changes in soil properties are largely biocharspecific and soil-specific as well (Lehmann et al. 2011; Gul et al. 2015; Pokharel et al. 2020).

In recent years, the use of biochar in metal-contaminated soils has gained widespread attention, because soil amendment with biochar was reported to immobilize and retain toxic metals in the soil (Ahmad et al. 2014; Bolan et al. 2014; Yuan et al. 2019; Palansooriya et al. 2020; Wang et al. 2020), thereby alleviating the potential toxicity of heavy metals to soil microbial community and biochemical functions (Park et al. 2011; Yang et al. 2016; Nie et al. 2018; Xu et al. 2018; Bashir et al. 2018, 2019). Biochar can also have a positive impact on microbial activity and enzymatic activity through its potential direct and indirect effects on soil physical, chemical and nutritional characteristics, particularly the build-up of SOM (Xu et al. 2018; Bashir et al. 2018; Song et al. 2019; Pokharel et al. 2020).

Nevertheless, very little is known about how biochar would influence the microbial and biochemical functions in soils simultaneously polluted with $\mathrm{Cd}$ and $\mathrm{Pb}$ (Xu et al. 2018). In co-contaminated soils, a metal may contribute to the release of other metals to soil solution and consequently would enhance the availability of the released metals (Ni et al. 2019; Fan et al. 2020; Jiang et al. 2020). In single-metal contamination, the biochar derived from digested sludge showed much greater adsorption capacity for $\mathrm{Pb}$ than for $\mathrm{Cd}$ from aqueous solution, and $\mathrm{Cd}$ adsorption on biochar was strongly reduced in metal co-contaminated systems ( $\mathrm{Ni}$ et al. 2019). Application of biochar produced from wheat straw at $700{ }^{\circ} \mathrm{C}$ was shown to immobilize both $\mathrm{Cd}$ and $\mathrm{Pb}$ in co-contaminated soils and decrease their concentrations in ryegrass biomass (Jiang et al. 2020). Recently, Jiang et al. (2020) reported that Pb immobilization was higher than Cd immobilization in both single and binary contamination of metals, which was attributed to the strong affinity of $\mathrm{Pb}$ than $\mathrm{Cd}$ for binding to biochar surface sites when they coexist in the soil. Microbial activity and biomass were lower in $\mathrm{Cd}$ and $\mathrm{Pb}$ co-contaminated soils than in the soils spiked with $\mathrm{Cd}$ or $\mathrm{Pb}$ alone, and addition of macadamia nutshell biochar at 5\% reduced metal toxicity (Xu et al. 2018).

The annual production of sugarcane bagasse, a major feedstock resource during the sugarcane refining process (Sarker et al. 2017), was estimated to be approximately 2.4 million tons in the Iranian sugarcane industry, Khuzestan province (Mohammadi et al. 2020). Previous works have demonstrated that biochar derived from sugarcane bagasse is an important source of organic matter and a valuable amendment to ameliorate the chemical, physical and biological fertility of soils with low organic matter content (Azeem et al. 2019; Bento et al. 2019; Zafar-ul-Hye et al. 2020; Rahman et al. 2021). Sugarcane bagasse biochar is characterized by high specific surface area, abundant micropores and high surface functional groups (Moradi-Choghamarani et al. 2019), which can sorb and immobilize heavy metal ions (Ding et al. 2014; Sarker et al. 2017; Bashir et al. 2018; Zahedifar and Moosavi 2020). Several studies have suggested that sugarcane bagasse-derived biochar could be used as a potential sorbent for metal removal and immobilization to remediate metal-contaminated soils, and to decrease metal toxicity to the soil microbial community (Bashir et al. 2018; Nie et al. 2018) and plants (Mohamed et al. 2019). However, limited information is available on how soil application of sugarcane bagasse biochar influences microbial properties and performance in metal-polluted soils (Nie et al. 2018). Such knowledge would be useful to use biochars generated from sugarcane bagasse for metal immobilization and to alleviation of metal toxicity to the soil microbial community and functions. Thus, the main aim of this research was to determine the response of microbial and biochemical properties to application of sugarcane bagasse biochar to a soil co-polluted simultaneously with $\mathrm{Cd}$ and $\mathrm{Pb}$. The main hypotheses were that (1) the use of bagasse biochar would reduce the toxicity of $\mathrm{Cd}$ and $\mathrm{Pb}$ to the activity and biomass of microbial community and enzyme activity in co-contaminated soils, and (2) the efficacy of biochar on the microbial and biochemical functions would be lower in co-spiked soils than single-spiked soils, likely due to competitive sorption between metals. 


\section{Materials and methods}

\subsection{Soil and biochar preparation}

A cropland soil sample (clay loam, Typic Calcixerepts, 0-20 cm depth) was collected from the Shahrekord Plain ( $\left.32^{\circ} 19^{\prime} 41^{\prime \prime} \mathrm{N}, 50^{\circ} 47^{\prime} 37^{\prime \prime} \mathrm{E}\right)$. The soil sample was sieved $(<2 \mathrm{~mm})$ and analyzed for physicochemical properties with the following values: Clay $=315 \mathrm{~g} \mathrm{~kg}^{-1}$; silt $=401 \mathrm{~g} \mathrm{~kg}^{-1}$; sand $=284 \mathrm{~g} \mathrm{~kg}^{-1} ; \mathrm{CaCO}_{3}=280 \mathrm{~g} \mathrm{~kg}^{-1}$; $\mathrm{pH}(1: 2$ ratio $)=7.9$; electrical conductivity (EC, $1: 2$ ratio $)=0.31 \mathrm{dS} \mathrm{m}^{-1}$; organic carbon $(\mathrm{OC})=4.7 \mathrm{~g} \mathrm{~kg}^{-1}$; cation exchange capacity $(\mathrm{CEC})=30.1 \mathrm{cmol}_{\mathrm{c}} \mathrm{kg}^{-1}$; field capacity $(\mathrm{FC})=21.2 \%(\mathrm{w} / \mathrm{w})$; total $\mathrm{Cd}$ and $\mathrm{Pb}=0.2$ and $20 \mathrm{mg} \mathrm{kg}^{-1}$, respectively. The measured concentrations of available $\mathrm{Cd}$ and $\mathrm{Pb}$ using DTPA-TEA (diethylene triamine penta acetic acid-triethanol amine) extractant were 0 and $0.6 \mathrm{mg} \mathrm{kg}^{-1}$, respectively. The biochars were prepared from sugarcane bagasse feedstock by slow pyrolysis at $400(\mathrm{~B} 400)$ and $600(\mathrm{~B} 600){ }^{\circ} \mathrm{C}$ for $120 \mathrm{~min}$ under limited supply of oxygen using a muffle furnace (Khadem and Raiesi 2017). The physicochemical properties of the bagasse-derived biochars were determined following the methods described by Khadem and Raiesi (2017). The measured characteristics of the biochars are presented in Table 1.

\subsection{Experimental layout and soil incubation}

This laboratory experiment was conducted using a completely randomized factorial design with two factors. The factors used in the present study included: (i) metal contamination $\left(10 \mathrm{mg} \mathrm{Cd} \mathrm{kg}^{-1}\right.$ as the single Cd contamination, $150 \mathrm{mg} \mathrm{Pb} \mathrm{kg}^{-1}$ as the single $\mathrm{Pb}$ contamination and $10 \mathrm{mg} \mathrm{Cd} \mathrm{kg}-150 \mathrm{mg} \mathrm{Pb} \mathrm{kg}{ }^{-1}$ as the co-contamination) and (ii) biochar application (CK, without biochar, B400 and B600 at 1\%, w/w), each with three replications $(n=3)$. The study soil was polluted using $\mathrm{Cd}$ chloride and $\mathrm{Pb}$ chloride solutions to achieve the above concentrations. Metal-polluted soils were homogenized for the entire distribution of the metals in the soil matrix. The samples were remoistened at $60-70 \%$ of the FC, and kept at room tempreature (about $20 \pm 5{ }^{\circ} \mathrm{C}$ ) for 4 weeks. The polluted soils were then treated with the organic amendments. The soil-biochar mixtures were then mixed thoroughly for a uniform distribution of biochar particles in the soil matrix. To lessen the impact of soil preparation, and to reactivate the soil microorganisms, the treated soils were remoistened at $60-70 \% \mathrm{FC}$ and pre-incubated at room temperature for 20 days. Ultimately, the soil samples were
Table 1 The basic properties of the bagasse biochars produced at 400 (B400) and $600(\mathrm{~B} 600)^{\circ} \mathrm{C}$

\begin{tabular}{lll}
\hline Property & $\mathrm{B} 400$ & $\mathrm{~B} 600$ \\
\hline Yield (\%) & 38.8 & 27.2 \\
Ash $(\%)$ & 29.6 & 35.3 \\
$\mathrm{pH}$ & $9.20(1: 20)$ & $9.90(1: 20)$ \\
Electrical conductivity $\left(\mathrm{dS} \mathrm{m}^{-1}\right)$ & $1.0(1: 20)$ & $1.9(1: 20)$ \\
Cation exchange capacity $\left(\mathrm{cmol}_{\mathrm{c}} \mathrm{kg}^{-1}\right)$ & 4.00 & 2.60 \\
Specific surface area $\left(\mathrm{m}^{2} \mathrm{~g}^{-1}\right)$ & 10.4 & 97.3 \\
Carbon $(\mathrm{C})\left(\mathrm{g} \mathrm{kg}^{-1}\right)$ & 529 & 547 \\
Nitrogen $(\mathrm{N})\left(\mathrm{g} \mathrm{kg}^{-1}\right)$ & 4.8 & 5.6 \\
Hydrogen $\left(\mathrm{H}^{-1}\left(\mathrm{~g} \mathrm{~kg}^{-1}\right)\right.$ & 31 & 14 \\
Sulfur $(\mathrm{S})\left(\mathrm{g} \mathrm{kg}^{-1}\right)$ & 0.40 & 0.60 \\
Oxygen $(\mathrm{O})\left(\mathrm{g} \mathrm{kg}^{-1}\right)$ & 134 & 86 \\
C:N molar ratio & 127 & 113 \\
O:C molar ratio & 0.19 & 0.12 \\
$\mathrm{H}: \mathrm{C}$ molar ratio & 0.70 & 0.31 \\
H:O molar ratio & 3.70 & 2.60 \\
Volatile matter $(\%)$ & 54.1 & 41.4 \\
Fixed C $(\%)$ & 23.1 & 36.0 \\
Cadmium $\left(\mathrm{mg} \mathrm{kg}^{-1}\right)$ & 0.18 & 0.20 \\
Lead (mg kg-1) & 5.00 & 5.50 \\
Iron (mg kg & 680 & 741 \\
Manganese $\left(\mathrm{mg} \mathrm{kg}^{-1}\right)$ & 68.7 & 76.2 \\
Copper $\left(\mathrm{mg} \mathrm{kg}^{-1}\right)$ & 7.00 & 7.60 \\
Zinc (mg kg-1) & 88.1 & 79.6 \\
Potassium $\left(\mathrm{g} \mathrm{kg}^{-1}\right)$ & 5.95 & 8.01 \\
Phosphorus $\left(\mathrm{mg} \mathrm{kg}^{-1}\right)$ & 186 & 342 \\
Sodium $\left(\mathrm{g} \mathrm{kg}^{-1}\right)$ & 1.16 & 1.38 \\
Calcium $\left(\mathrm{g} \mathrm{kg}^{-1}\right)$ & 27.7 & 35.0 \\
Magnesium $\left(\mathrm{g} \mathrm{kg}^{-1}\right)$ & 8.06 & 11.6 \\
\hline
\end{tabular}

adjusted to $65 \pm 5 \%$ of the $\mathrm{FC}$ and incubated for 4 months at $25 \pm 1{ }^{\circ} \mathrm{C}$.

\subsection{Soil analysis for microbial properties}

In this experiment, we used several microbial assays (i.e., C mineralization, basal respiration, substrate-induced respiration and microbial biomass) as the toxicological endpoints (Kuperman et al. 2014; Raiesi and Dayani 2021). Soil C mineralization was determined as the $\mathrm{CO}_{2}$ evolved over a 120-day period using $0.5 \mathrm{M} \mathrm{NaOH}$ for trapping the respired $\mathrm{CO}_{2}$ (Alef and Nannipieri 1995). The cumulative C mineralization (Cmin) was then calculated for the whole incubation period. The total biochar $\mathrm{C}$ mineralized (TCM, \%) was calculated as the ratio of the $\mathrm{Cmin}$ values over the amount of $\mathrm{C}$ added initially and used as a measure of biochar $\mathrm{C}$ turnover rate. At the end of the incubation period, basal respiration (BR) was quantified as the amount of microbial $\mathrm{CO}_{2}$ emitted from the treated soils over 4 weeks according to the method 
described above, and substrate-induced respiration (SIR) as the evolved $\mathrm{CO}_{2}$ from glucose-amended soils over 5-6 h following the method described in Lin and Brookes (1999). Microbial biomass carbon (MBC) was quantified using the fumigation-incubation method as described by Joergensen (1995). The microbial quotient (qM), the ratio of MBC to OC expressed as \%, was calculated to provide an indicator of substrate availability for the microbial population or conversion efficiency of OC into microbial biomass. The metabolic quotient $\left(q \mathrm{CO}_{2}\right)$ was also calculated by dividing BR by MBC values (the $\mathrm{CO}_{2}-\mathrm{C}$ respired per MBC per day) and used as an indicator of stress to the microbial community (Anderson and Domsch 2010).

Furthermore, the activities of soil urease (URE), alkaline phosphomonoesterase (ALP) and arylsulphatase (ARY) were determined (Alef and Nannipieri 1995). Soil catalase (CAT) activity was measured according to the method described by Liu et al. (2008), by the back titration of residual hydrogen peroxide $\left(\mathrm{H}_{2} \mathrm{O}_{2}\right)$ with $\mathrm{KMnO}_{4}$ and the activity of dehydrogenase (DEH) was assayed by determining the amount of triphenyl formazan released from the reduction of the triphenyl tetrazolium chloride (Alef and Nannipieri 1995). The fluorescein diacetate hydrolysis (FDA) activity was measured colorimetrically using fluorescein diacetate as substrate according to the method described by Green et al. (2006). Soil enzyme activities are not considered as the toxicological endpoints, since the enzymatic activities are measured at conditions that are not representative for in situ conditions (Kuperman et al. 2014), and, therefore, their ecological relevance is uncertain for soil ecotoxicological risk assessment of heavy metals.

Soil pH, EC, OC and DTPA-extractable $\mathrm{Cd}$ and $\mathrm{Pb}$ concentrations (Lindsay and Norvell 1978) were also determined at the end of the incubation period. Soil dissolved organic carbon (DOC) content was determined by following the procedure as outlined by Guo et al. (2015).

\subsection{Statistical analysis}

We used two-way analysis of variance (ANOVA) to examine the impact of metal contamination, biochar application, and their interaction on soil properties. The soil datasets were tested for the homogeneity of variance and normality before statistical analysis using the procedure described by Kozak and Piepho (2018). The mean values were compared based on the Tukey's test at 5\% level of significance $(P \leq 0.05)$. The software Minitab (Minitab 18.1) was used for all statistical analyses. Soil datasets were also subjected to a redundancy analysis (RDA) as a constrained ordination model to evaluate the correlation of microbial properties and enzyme activities as response variables with soil chemical properties as explanatory variables using the CANOCO 4.5 software for Windows. For the RDA model, each RDA axis and explanatory variables were tested using a Monte Carlo permutation test in CANOCO.

\section{Results}

\subsection{Soil chemical properties}

The effects of biochar addition on soil $\mathrm{pH}$ and EC were statistically $(P \leq 0.05)$ significant (Fig. 1$)$. Soil $\mathrm{pH}$ increased by 0.1 units and EC decreased by 0.1 units only with addition of B400. Although significant, the effects of B400 on soil $\mathrm{pH}$ and EC were small and these changes are unlikely to be a factor to influence the availability of metals in the current experiment. Generally, the DTPA-extractable metal $(\mathrm{Cd}$ and $\mathrm{Pb})$ concentrations were considerably higher with the co-presence of metals compared with the single metals, regardless of the biochar application (Fig. 1). The results of two-way ANOVA indicated that the DTPA-extractable metal concentrations were significantly affected by the main effects of pollution treatment $(P \leq 0.001)$, biochar addition $(P \leq 0.001)$ and their interaction $(P \leq 0.001)$. Biochar application decreased the DTPAextractable Cd concentration by $14-18 \%$ in Cd-contaminated soil and by $16-18 \%$ in co-contaminated soil compared with the control (Fig. 1). The reduction of $\mathrm{Cd}$ availability with addition of B600 and B400 was $18 \%$ and 14\%, respectively, in Cd-contaminated soils but did not differ between the two biochars in co-contaminated soils. With addition of B400, the declined Cd availability was greater in co-spiked soils (16\%) than in singlespiked soils (14\%). Similarly, biochar addition decreased the DTPA-extractable $\mathrm{Pb}$ by $10-22 \%$ in $\mathrm{Pb}$-contaminated soils and $12-16 \%$ in $\mathrm{Cd}+\mathrm{Pb}$ co-contaminated soils when compared with the control without biochar, with greater reductions in B600 than B400 treatments (Fig. 1). In B400-treated soils, the decreased $\mathrm{Pb}$ availability was greater in co-contaminated soils (12\%) than in single-contaminated soils (10\%) while a reverse trend was observed in B600-treated soils (16 vs. $22 \%)$. Furthermore, the decrease of Cd availability (16-18\%) with biochar addition was larger than that of $\mathrm{Pb}$ availability (12-16\%) in co-spiked soils compared with the corresponding control. The amount of soil OC was significantly increased by $94-100 \%$ after addition of both biochars across contaminated soils compared to the control, from $4.61 \mathrm{~g} \mathrm{~kg}^{-1}$ in the unamended soil to $8.93 \mathrm{~g} \mathrm{~kg}^{-1}$ in B400-amended soils and $9.23 \mathrm{~g} \mathrm{~kg}^{-1}$ in B600-amended soils (Fig. 1). The increased soil OC pool was greater in B600 (100\%) than B400 (94\%) treatments. When compared with the unamended control, B400 biochar increased the content of DOC under individual Cdcontamination. The increased DOC content was much higher with B400 (42-50\%) than with B600 (17-19\%) under both individual $\mathrm{Pb}$ and co-contamination. 

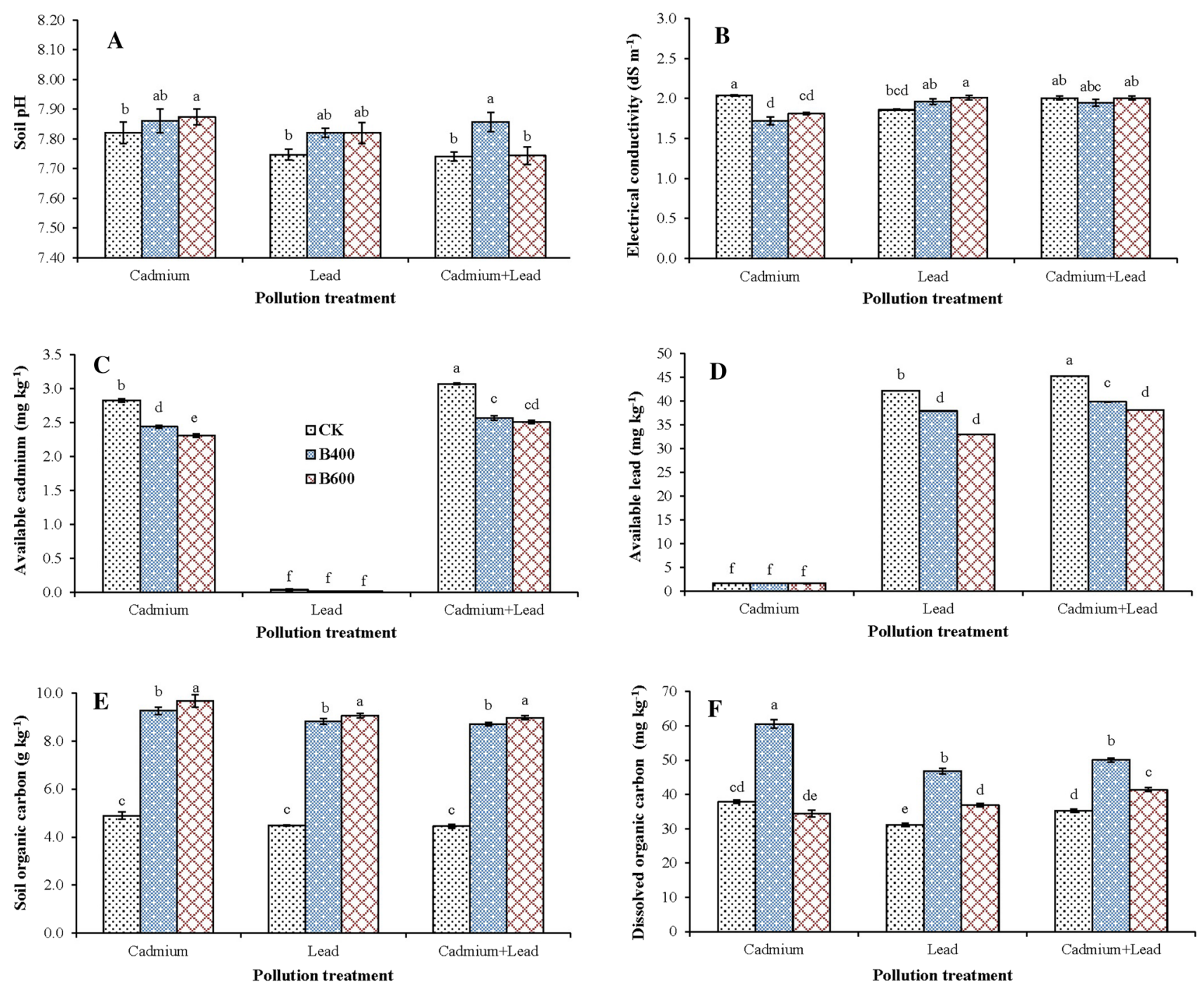

Fig. 1 Effect of sugarcane bagasse biochar on soil pH (A), electrical conductivity (B), the concentrations of DTPA-extractable cadmium (C) and lead (D), soil organic carbon (E) and dissolved organic carbon $(\mathbf{F})$ in metal-polluted soils. Values are mean $(n=3)$ and the vertical bars represent standard error of the mean. Different letters above

\subsection{Soil C mineralization}

The pattern of soil $\mathrm{C}$ mineralization during the 120 days of incubation is shown in Fig. 2. The soil $\mathrm{C}$ mineralization was very high during the first 50 days of incubation in all treatments, but the rates of increase in $\mathrm{C}$ mineralization tended to decrease subsequently. About $62-82 \%$ of the soil $\mathrm{C}$ was mineralized during the first 50 days of incubation when compared with that after 120 days. The $\mathrm{C}$ mineralization in biochar-amended soils was generally higher than that in unamended soils in all metal-spiked soils throughout the incubation with greater values in B400 than B600 treatments after 50 days (Fig. 2). Significant interactions $(P \leq 0.001)$ in the cumulative $\mathrm{C}$ mineralization $(\mathrm{Cmin})$

bars indicate significant differences among the treatment means by Tukey's post hoc test at $P \leq 0.05$ (CK, control soil; B400 and B600, soils amended with biochars produced at 400 and $600{ }^{\circ} \mathrm{C}$, respectively)

occurred between metal pollution and biochar treatments (Fig. 3). At the end of the 120-day soil incubation, the Cmin significantly increased $(75-135 \%)$ by biochar in all metal-spiked soils. The lowest Cmin values (186-196 mg $\mathrm{C} \mathrm{kg}^{-1}$ ) were recorded in all metal-spiked soils without amendment. The highest Cmin values (442-460 mg C $\mathrm{kg}^{-1}$ ) were observed with B400 in single metal-spiked soils, which were $126-135 \%$ higher than that of the corresponding control soil without biochar (195-196 mg C $\mathrm{kg}^{-1}$ ). In biochar-amended soils, the increase in Cmin was lower under $\mathrm{Cd}+\mathrm{Pb}(78-93 \%)$ relative to individual (75-135\%) metals (Fig. 3). The Cmin values were highly $(P \leq 0.001)$ correlated with soil OC $(r=0.89)$ and DOC $(r=0.70)$ contents (Table S1). After 120 days of 
Fig. 2 Effect of sugarcane bagasse biochar on carbon $(\mathrm{C})$ mineralization in soils spiked with cadmium $(\mathrm{Cd})$ and lead $(\mathrm{Pb})$ over 120 days of incubation. Values are mean $(n=3)$ and the vertical bars represent standard error of the mean $(\mathrm{CK}$, control soil; B400 and B600, soils amended with biochars produced at 400 and $600{ }^{\circ} \mathrm{C}$; respectively)
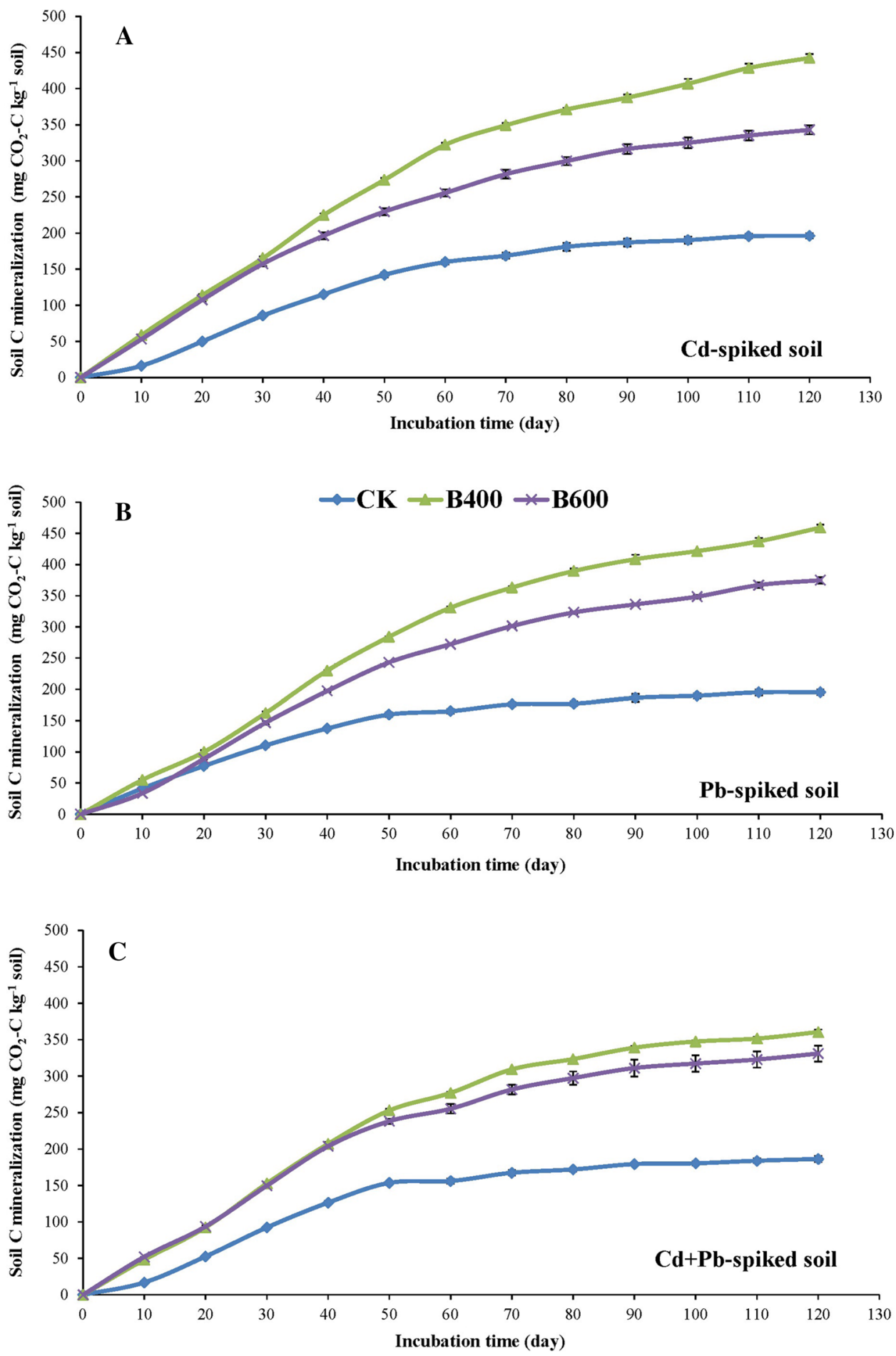

the laboratory incubation, the total biochar $\mathrm{C}$ mineralized (TCM) averaged across polluted soils was greater in B400 (3.6-4.6\%) than B600 (3.2-3.7\%) treatments (Fig. 3).

\subsection{Soil microbial activity and biomass}

There was also a significant interaction between metal pollution and biochar treatments on soil BR (Table 2). Soils polluted with $\mathrm{Cd}$ and $\mathrm{Pb}$ alone displayed the highest $\mathrm{BR}$ values (5.71-5.93 mg C kg${ }^{-1} \mathrm{day}^{-1}$ ) in B400 treatments, while all metal-contaminated soils showed the lowest BR 

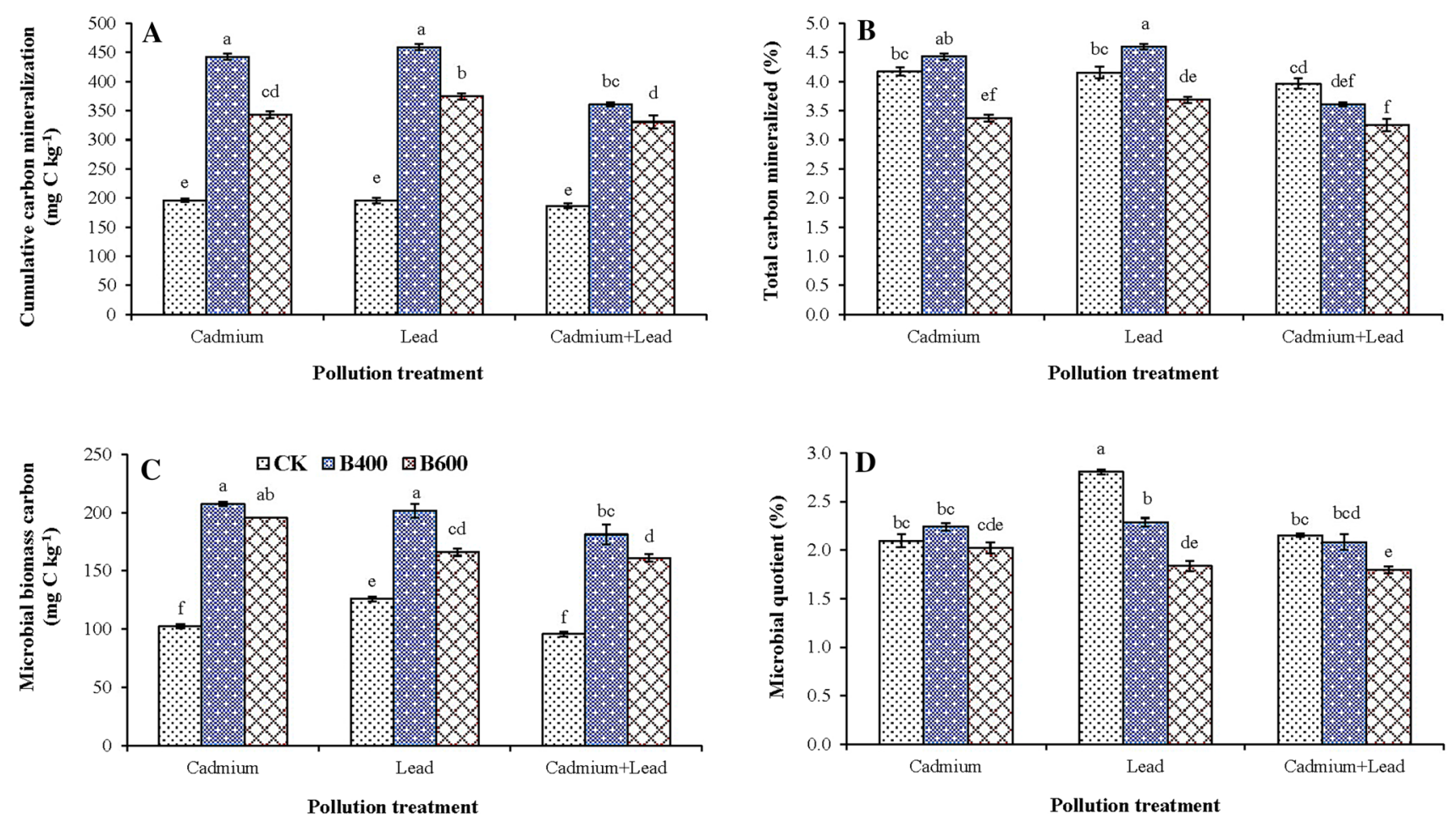

Fig. 3 Effect of biochar on cumulative carbon mineralization (A) and total $\mathrm{C}$ mineralized (B) over 120 days of incubation, microbial biomass carbon $(\mathbf{C})$ and microbial quotient $(\mathbf{D})$ in soils spiked with cadmium $(\mathrm{Cd})$ and lead $(\mathrm{Pb})$. Values are mean $(n=3)$ and the vertical

bars represent standard error of the mean. Different letters above bars indicate significant differences among the treatment means by Tukey's post hoc test at $P \leq 0.05$ (CK, control soil; B400 and B600, soils amended with biochars produced at 400 and $600{ }^{\circ} \mathrm{C}$, respectively)

values (3.37-4.03 $\left.\mathrm{mg} \mathrm{C} \mathrm{kg}^{-1} \mathrm{day}^{-1}\right)$ in unamended treatments (Table 2). The BR increased significantly with biochar addition (by $30-70 \%$ ) and this effect was greater in B400 (44-56\%) than B600 (30-47\%) treatments in both $\mathrm{Cd}$-spiked and co-spiked soils. However, the substrateinduced respiration (SIR) was affected only by pollution $(P \leq 0.05)$ and biochar $(P \leq 0.001)$, and was lower in cospiked than $\mathrm{Pb}$-spiked soils (Table 3 ). Biochar addition increased the SIR with greater increases in B600 (67\%) than B400 (53\%). The BR was strongly correlated with OC and DOC, while the SIR was highly correlated only with DOC (Table S1).

The MBC content increased in biochar-amended soils by $32-103 \%$ in comparison with unamended soils (Fig. 3). However, the extent to which MBC was stimulated by biochar depended on the pyrolysis temperature and metal treatment. The increases in MBC were not different between B400 and B600 treatments in Cd-spiked soils while they were greater in B400-amended soils than B600-amended soils under $\mathrm{Pb}$ and $\mathrm{Cd}+\mathrm{Pb}$ spiked treatments. The microbial quotient (qM) remained unaffected by biochar in $\mathrm{Cd}-$ spiked soils, decreased by $18-35 \%$ in Pb-spiked soils, and decreased only by B600 (17\%) in co-spiked soils (Fig. 3). The MBC was positively correlated $(P \leq 0.001)$ with OC, DOC, BR, SIR and Cmin, whereas the qM negatively

correlated $(P \leq 0.01)$ with OC and SIR (Table S1). The $q \mathrm{CO}_{2}$ was highest $\left(36.3 \mu \mathrm{g} \mathrm{C} \mathrm{mg}^{-1} \mathrm{MBC} \mathrm{day}^{-1}\right)$ in the unamended co-spiked soil (Table 2). This microbial parameter significantly decreased by biochar application $(2-17 \%)$ and did not vary with pyrolysis temperature. The $q \mathrm{CO}_{2}$ was negatively correlated with OC, DOC and other microbial properties (Table S1).

\subsection{Biochar effects on soil enzyme activity}

Results showed that only the main effects of metal and biochar treatments on CAT activity were significant (Table 3), while the activities of other enzymes were interactively affected by metal and biochar treatments (Table 2). The activity of CAT was greater in $\mathrm{Pb}$-spiked soil than $\mathrm{Cd}$ or $\mathrm{Cd}+\mathrm{Pb}$ spiked soils, and stimulated equally by both biochars (Table 3 ). Biochar application improved DEH, ALP, URE, ARY and FDA activities in heavy metal-contaminated soils, depending on the pyrolysis temperature and metal treatment (Table 2). Addition of biochar significantly increased the activities of enzymes with a greater increase in DEH, ALP and ARY activities in B400 soils under individual Cd treatment, and in URE and FDA activities in B400 soils under individual $\mathrm{Pb}$ treatment. The increases in the DEH and ALP activities 
Table 2 Effect of bagasse biochar (CK, control soil; B400 and B600, soils amended with biochars produced at 400 and $600{ }^{\circ} \mathrm{C}$, respectively) on basal respiration, metabolic quotient and the activities of soil enzymes in metal-contaminated soils

\begin{tabular}{|c|c|c|c|c|c|}
\hline \multirow[t]{2}{*}{ Biochar treatment } & \multicolumn{3}{|l|}{ Pollution treatment } & \multicolumn{2}{|c|}{ ANOVA summary } \\
\hline & Cadmium $(\mathrm{Cd})$ & Lead $(\mathrm{Pb})$ & $\mathrm{Cd}+\mathrm{Pb}$ & Effect & $P$ \\
\hline \multicolumn{6}{|c|}{ Basal respiration ( $\mathrm{mg} \mathrm{C} \mathrm{kg}^{-1}$ day $^{-1}$ ) } \\
\hline CK & $3.37 \pm 0.01 \mathrm{f}$ & $4.04 \pm 0.03 \mathrm{e}$ & $3.48 \pm 0.09 f$ & Pollution (P) & $<0.001$ \\
\hline B400 & $5.71 \pm 0.03 \mathrm{a}$ & $5.83 \pm 0.03 \mathrm{a}$ & $5.43 \pm 0.07 \mathrm{bc}$ & Biochar (B) & $<0.001$ \\
\hline $\mathrm{B} 600$ & $5.64 \pm 0.03 \mathrm{ab}$ & $5.26 \pm 0.06 \mathrm{~cd}$ & $5.13 \pm 0.05 d$ & $\mathrm{P} \times \mathrm{B}$ & $<0.001$ \\
\hline \multicolumn{6}{|c|}{ Metabolic quotient $\left(\mu \mathrm{g} \mathrm{C} \mathrm{mg}^{-1} \mathrm{MBC}\right.$ day $^{-1}$ ) } \\
\hline CK & $32.9 \pm 0.53 b$ & $32.1 \pm 0.37 b$ & $36.3 \pm 0.35 a$ & Pollution (P) & $<0.001$ \\
\hline B400 & $27.5 \pm 0.39 \mathrm{~d}$ & $29.0 \pm 0.95 \mathrm{~cd}$ & $30.0 \pm 1.04 \mathrm{bcd}$ & Biochar (B) & $<0.001$ \\
\hline B600 & $28.9 \pm 0.15 \mathrm{~cd}$ & $31.6 \pm 0.24 \mathrm{bc}$ & $31.8 \pm 0.45 b$ & $\mathrm{P} \times \mathrm{B}$ & $<0.05$ \\
\hline \multicolumn{6}{|c|}{ Dehydrogenase activity $\left(\mu \mathrm{mol}\right.$ TPF $\left.\mathrm{g}^{-1} \mathrm{~h}^{-1}\right)$} \\
\hline CK & $0.167 \pm 0.0005 f$ & $0.181 \pm 0.0001 \mathrm{e}$ & $0.148 \pm 0.0012 \mathrm{~g}$ & Pollution (P) & $<0.001$ \\
\hline B400 & $0.369 \pm 0.0010 \mathrm{a}$ & $0.372 \pm 0.0012 \mathrm{a}$ & $0.292 \pm 0.0007 d$ & Biochar (B) & $<0.001$ \\
\hline B600 & $0.348 \pm 0.0002 \mathrm{c}$ & $0.362 \pm 0.0006 b$ & $0.290 \pm 0.0015 \mathrm{~d}$ & $\mathrm{P} \times \mathrm{B}$ & $<0.001$ \\
\hline \multicolumn{6}{|c|}{ Alkaline phosphomonoesterase activity $\left(\mu \mathrm{mol} \mathrm{PNP} \mathrm{g}{ }^{-1} \mathrm{~h}^{-1}\right)$} \\
\hline CK & $9.80 \pm 0.18 \mathrm{e}$ & $14.2 \pm 0.08 \mathrm{~b}$ & $10.5 \pm 0.11 \mathrm{e}$ & Pollution (P) & $<0.001$ \\
\hline B400 & $13.5 \pm 0.14 \mathrm{bc}$ & $16.6 \pm 0.17 \mathrm{a}$ & $14.0 \pm 0.15 b c$ & Biochar (B) & $<0.001$ \\
\hline В600 & $12.0 \pm 0.30 \mathrm{~d}$ & $13.7 \pm 0.23 \mathrm{bc}$ & $13.1 \pm 0.13 \mathrm{bc}$ & $\mathrm{P} \times \mathrm{B}$ & $<0.01$ \\
\hline \multicolumn{6}{|c|}{ Urease activity $\left(\mu \mathrm{mol} \mathrm{NH}_{4}-\mathrm{N} \mathrm{g}^{-1} \mathrm{~h}^{-1}\right)$} \\
\hline CK & $2.47 \pm 0.01 \mathrm{e}$ & $2.37 \pm 0.05 \mathrm{e}$ & $2.36 \pm 0.02 \mathrm{e}$ & Pollution (P) & $<0.001$ \\
\hline B400 & $4.20 \pm 0.01 \mathrm{a}$ & $4.16 \pm 0.03 \mathrm{ab}$ & $3.02 \pm 0.04 \mathrm{~d}$ & Biochar (B) & $<0.001$ \\
\hline B600 & $4.01 \pm 0.21 b$ & $4.20 \pm 0.05 \mathrm{a}$ & $3.21 \pm 0.06 \mathrm{c}$ & $\mathrm{P} \times \mathrm{B}$ & $<0.001$ \\
\hline \multicolumn{6}{|c|}{ Arylsulphatase activity $\left(\mu \mathrm{mol} \mathrm{PNP} \mathrm{g}^{-1} \mathrm{~h}^{-1}\right)$} \\
\hline CK & $2.36 \pm 0.08 \mathrm{f}$ & $3.18 \pm 0.10 \mathrm{~d}$ & $2.74 \pm 0.04 \mathrm{e}$ & Pollution (P) & $<0.001$ \\
\hline B400 & $4.80 \pm 0.03 b$ & $5.47 \pm 0.06 \mathrm{a}$ & $3.44 \pm 0.06 \mathrm{~d}$ & Biochar (B) & $<0.001$ \\
\hline B600 & $4.22 \pm 0.04 c$ & $4.79 \pm 0.05 b$ & $3.21 \pm 0.06 \mathrm{~d}$ & $\mathrm{P} \times \mathrm{B}$ & $<0.001$ \\
\hline \multicolumn{6}{|c|}{ Fluorescein diacetate hydrolysis activity $\left(\mu \mathrm{mol}\right.$ fluorescein $\mathrm{g}^{-1} \mathrm{~h}^{-1}$ ) } \\
\hline CK & $0.163 \pm 0.0012 \mathrm{~g}$ & $0.161 \pm 0.0012 \mathrm{~g}$ & $0.142 \pm 0.0011 \mathrm{~h}$ & Pollution (P) & $<0.001$ \\
\hline B400 & $0.296 \pm 0.0010 \mathrm{~b}$ & $0.310 \pm 0.0012 \mathrm{a}$ & $0.240 \pm 0.0011 \mathrm{e}$ & Biochar (B) & $<0.001$ \\
\hline B600 & $0.262 \pm 0.0020 \mathrm{~d}$ & $0.283 \pm 0.0013 c$ & $0.228 \pm 0.0040 f$ & $\mathrm{P} \times \mathrm{B}$ & $<0.001$ \\
\hline
\end{tabular}

Values are mean \pm standard error of the mean $(n=3)$

Different letters represent significant differences by Tukey test at $P \leq 0.05$

\begin{tabular}{|c|c|c|c|c|c|}
\hline \multirow[t]{2}{*}{ Pollution treatme } & & \multicolumn{2}{|c|}{ Biochar treatment } & \multicolumn{2}{|c|}{ ANOVA summary } \\
\hline & & & & Effect & $P$ \\
\hline \multicolumn{6}{|c|}{ Substrate-induced respiration $\left(\mathrm{mg} \mathrm{C} \mathrm{kg}^{-1} \mathrm{~h}^{-1}\right)$} \\
\hline Cadmium (Cd) & $44.2 \pm 2.94 \mathrm{ab}$ & $\mathrm{CK}$ & $31.1 \pm 1.23 \mathrm{c}$ & Pollution (P) & $<0.05$ \\
\hline Lead $(\mathrm{Pb})$ & $46.2 \pm 4.04 \mathrm{a}$ & B400 & $47.5 \pm 1.28 b$ & Biochar (B) & $<0.001$ \\
\hline $\mathrm{Cd}+\mathrm{Pb}$ & $40.3 \pm 3.00 b$ & B 600 & $52.1 \pm 1.66 \mathrm{a}$ & $\mathrm{P} \times \mathrm{B}$ & $>0.05$ \\
\hline \multicolumn{6}{|c|}{ Catalase activity $\left(\mu \mathrm{mol} \mathrm{O} \mathrm{g}^{-1} \mathrm{~h}^{-1}\right)$} \\
\hline Cadmium (Cd) & $2.43 \pm 0.03 b$ & CK & $2.30 \pm 0.02 b$ & Pollution (P) & $<0.001$ \\
\hline Lead $(\mathrm{Pb})$ & $2.52 \pm 0.05 \mathrm{a}$ & B400 & $2.55 \pm 0.03 \mathrm{a}$ & Biochar (B) & $<0.001$ \\
\hline $\mathrm{Cd}+\mathrm{Pb}$ & $2.39 \pm 0.04 b$ & B 600 & $2.49 \pm 0.03 a$ & $\mathrm{P} \times \mathrm{B}$ & $>0.05$ \\
\hline
\end{tabular}

Values are mean \pm standard error of the mean $(n=9)$

Different letters represent significant differences by Tukey test at $P \leq 0.05$
Table 3 Effect of bagasse biochar (CK, control soil; B400 and B600, soils amended with biochars produced at 400 and $600{ }^{\circ} \mathrm{C}$, respectively) on substrate-induced respiration and catalase activity in metalcontaminated soils
URE activity was much greater in B400 than B600 treatments only in single $\mathrm{Cd}$ and co-contaminated soils. In addition, enzyme activities were lower under $\mathrm{Cd}+\mathrm{Pb}$ than 
under individual metals, except ALP (Table 3). The ALP activity did not show a clear trend with metal treatments across the biochar treatment. The ALP, ARY and CAT activities were negatively correlated with the concentration of available $\mathrm{Cd}$ but not with available $\mathrm{Pb}$ (Table $\mathrm{S} 1$ ). All enzyme activities were positively correlated with OC, BR, SIR and MBC. Generally, enzyme activities were highly correlated with each other (Table S1).

\subsection{RDA ordination of soil dataset}

The variations in soil microbial attributes and enzyme activities among the treatments were also analyzed by RDA ordination method (Fig. 4). The RDA results showed that soil chemical attributes (OC, DOC, DTPA-extractable Cd and $\mathrm{Pb}$ ) explained a significant portion of soil microbial and biochemical properties. Two RDA axes were significant and together were responsible for $95 \%$ of the total variability in soil microbial properties. The first axe accounted for $94.5 \%$ and the second axe explained only $0.5 \%$ of the total variation in soil microbial properties (Fig. 4A). The soil OC $(F=101.6, P=0.001)$ was the most highly significant variable explaining $80 \%$ of the variance in microbial properties, followed by available Cd concentration $(8 \%, F=32.5$, $P=0.001)$ and DOC $(7 \%, F=13.6, P=0.001)$ across treatments (Fig. 4A). RDA results showed that the first axe was associated with about $79 \%$ of the total variation in enzyme activities, and the second axe accounted for $5.5 \%$ of the variability (Fig. 4B). Soil OC ( $F=25.6, P=0.001)$, available $\mathrm{Cd}(F=25.1, P=0.001)$, DOC $(F=7.25, P=0.006)$ and available $\mathrm{Pb}(F=3.25, P=0.049)$ were significantly correlated with enzyme activities and explained 51, 25, 6\% and $2 \%$ of the total variability in enzyme activity, respectively (Fig. 4B).

\section{Discussion}

Application of biochars $\left(400\right.$ and $\left.600{ }^{\circ} \mathrm{C}\right)$ derived from sugarcane bagasse lowered the availability of both $\mathrm{Cd}$ and $\mathrm{Pb}$ in singly and jointly contaminated soils. This confirms that the potential risk of soil $\mathrm{Cd}$ and $\mathrm{Pb}$ biotoxicity could be lowered with addition of bagasse biochars to metal-contaminated soils. Other short-term laboratory studies also found that addition of biochar derived from sugarcane bagasse had the potential to immobilize $\mathrm{Cd}$ and $\mathrm{Pb}$ in soil (Lu et al. 2017; Bashir et al. 2018, 2019; Nie et al. 2018) and remove $\mathrm{Pb}$ from aqueous solution (Ding et al. 2014). Metal immobilization with biochar application is mainly attributed to different chemical reactions (Ding et al. 2014; Palansooriya et al. 2020; Wang et al. 2020). Biochar application to soil can immobilize metals through increasing binding sites for metal ions (Ahmad et al. 2014; Yuan et al. 2019). In this study,
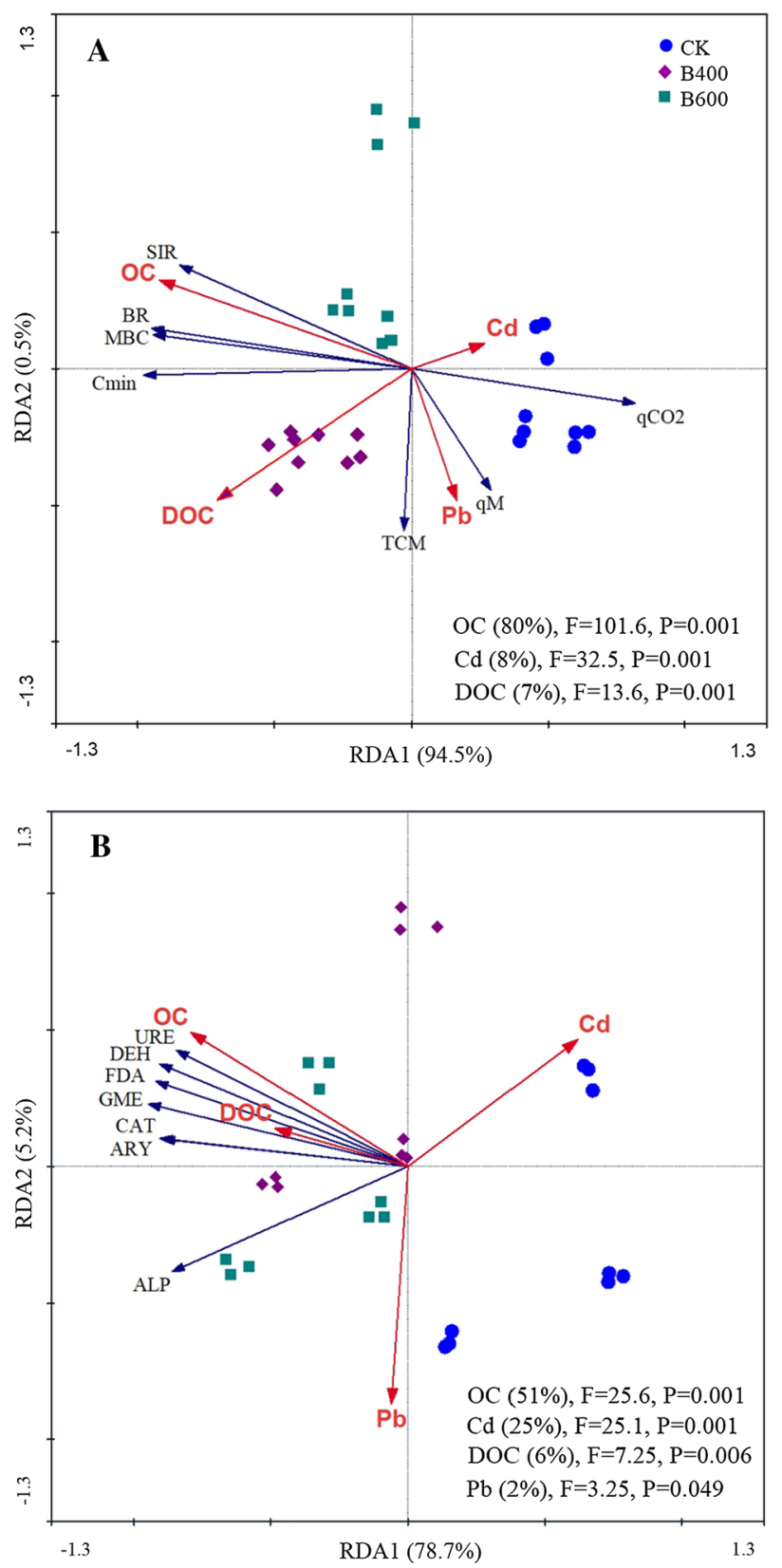

Fig. 4 Redundancy analysis (RDA) ordination of the microbial properties (A) and enzyme activities (B) constrained by soil chemical properties in metal-contaminated soils amended with biochar. The red arrows display explanatory variables (soil chemical properties) and response variables (microbial properties and enzyme activities) are shown in blue vectors. The corresponding proportion of the variability explained $F$ and $P$ values are shown on the figures. Filled circles show soil samples (abbreviations: $C d$ available cadmium; $P b$ available lead; $O C$ soil organic carbon; $D O C$ dissolved organic carbon; $B R$ basal respiration; SIR substrate-induced respiration; $C$ min cumulative $\mathrm{C}$ mineralization; $T C M$ total biochar $\mathrm{C}$ mineralized; $M B C$ microbial biomass carbon; $q M$ microbial quotient; $q \mathrm{CO}_{2}$ metabolic quotient; $D E H$ dehydrogenase activity; $F D A$ fluorescein diacetate hydrolysis; $A L P$ alkaline phosphomonoesterase activity; $U R E$ urease activity; $A R Y$ arylsulphatase urease activity; $C A T$ catalase activity, GME geometric mean of enzyme activity) 
despite the high $\mathrm{pH}(9.2-9.9)$ and alkalinity of the biochars (Table 1), biochar application did not have a major effect on soil $\mathrm{pH}$, which is known to control the solubility and mobility of heavy metals in biochar-amended soils (Bolan et al. 2014; Yuan et al. 2019; Wang et al. 2020). This is consistent with previous studies (Khadem and Raiesi 2017; Bashir et al. 2018), which reported the small changes in the $\mathrm{pH}$ of neutral and alkaline soils following addition of biochars derived from sugarcane bagasse. Bashir et al. (2018) reported that increases in soil $\mathrm{pH}$ were not always significant in slightly alkaline $(\mathrm{pH} 7.5)$ soils amended with sugarcane bagasse-derived biochar. We observed that the availability of $\mathrm{Cd}$ and $\mathrm{Pb}$ was higher in the metal co-contaminated soils than the single metal-contaminated soils either unamended or amended with both biochars; consistent with earlier reports (Khan et al. 2010; Xu et al. 2018, 2019; Fan et al. 2020). This suggests a possible competition between $\mathrm{Cd}$ and $\mathrm{Pb}$ for the adsorption sites on biochar and soil surfaces when both metals coexisted in the soil (Park et al. 2016; Ni et al. 2019). Surprisingly, the reduction of $\mathrm{Cd}$ availability (16\%) was greater than that of $\mathrm{Pb}$ availability $(12 \%)$ in co-contaminated soils amended with low-temperature bagasse biochar. This finding suggests a greater immobilization of $\mathrm{Cd}$ than $\mathrm{Pb}$ by low-temperature biochar under competitive adsorption conditions. Similarly, addition of macadamia nutshell biochar $(5 \%$ w/w) to $\mathrm{Cd}$ and $\mathrm{Pb}$ co-spiked soils reduced metal availability during 49 days of incubation, and the decline of $\mathrm{Cd}$ availability was greater than that of $\mathrm{Pb}$ (Xu et al. 2018). In a recent experiment (Fan et al. 2020), addition of modified rice straw biochar to a soil naturally co-contaminated with $\mathrm{Cd}\left(9.18 \mathrm{mg} \mathrm{kg}^{-1}\right)$ and $\mathrm{Pb}\left(1182 \mathrm{mg} \mathrm{kg}^{-1}\right)$ reduced the DTPA-extractable Cd concentrations (34.8-39.2\%) more than the DTPA-extractable $\mathrm{Pb}$ concentrations (8.6-11.1\%) during a 28-day incubation period. In contrast, other studies (Park et al. 2011, 2016; Inyang et al. 2012; Jiang et al. 2020) reported greater $\mathrm{Pb}$ than $\mathrm{Cd}$ adsorption on biochar surfaces under competitive adsorption conditions. Nevertheless, Inyang et al. (2012) indicated that biochar type is an important factor under competitive adsorption conditions. They reported that the removal of $\mathrm{Cd}$ from aqueous solution was greater than that of $\mathrm{Pb}$ for digested whole sugar beet biochar, but the removal of $\mathrm{Pb}$ was greater than that of Cd for digested dairy waste biochar (Inyang et al. 2012). For these cases, surface electrostatic interaction might not be an overriding mechanism for metal removal, and other possible mechanisms, such as surface co-precipitation, surface complexation and intraparticle diffusion, should also be involved in metal immobilization (Inyang et al. 2012; Ding et al. 2014). Nonetheless, further studies are needed to validate this conclusion using the well-established adsorption isotherms such as Langmuir and Freundlich isotherms in soil-biochar mixtures. Our finding suggests that $\mathrm{Pb}$ toxicity and thus the potential risk to microbial population and activity could be greater than $\mathrm{Cd}$ toxicity in $\mathrm{Cd}+\mathrm{Pb}$ cocontaminated soils.

In this incubation experiment, the immobilization capacity of the high-temperature biochar for $\mathrm{Pb}(16 \%)$ was greater than that of the low-temperature biochar (12\%) in co-spiked soils, and both biochars equally affected $\mathrm{Cd}$ immobilization. This finding suggests that $\mathrm{Pb}$ showed greater affinity to the high-temperature bagasse biochar, which could be attributed to the transformation of $\mathrm{Pb}$ into more stable $\mathrm{Pb}$-phosphate fractions (Ding et al. 2014). In the present study, the P content in biochars increased substantially with the increase of pyrolysis temperature (Table 1).

Soil microbial communities are the main driving agents responsible for the long-term sustainability of terrestrial ecosystems because they regulate the formation and decomposition of SOM and plant residues, the cycling and availability of essential nutrients, $\mathrm{C}$ cycling and sequestration, biodegradation of harmful organic pollutants as well as biotransformation of toxic metals in the soil (Abdu et al. 2017; Nannipieri et al. 2017; Xu et al. 2019). Microbial and biochemical properties are sensitive indicators of soil health and ecological risks in polluted environments (Khan et al. 2010; Abdu et al. 2017; Xu et al. 2018), and are improved by biochar amendment (Lehmann et al. 2011; Gul et al. 2015; Khadem and Raiesi 2017). The results presented here suggest that biochar addition promotes microbial functions in metal-contaminated soils, as evidenced by significant increases in microbial and biochemical indicators. Previous experiments have similarly illustrated significant positive influences of sugarcane bagasse biochar on microbial activity and biomass, and enzyme activities in metalcontaminated soils under field and laboratory conditions (Nie et al. 2018; Bashir et al. 2018, 2019). These results suggest that the use of sugarcane bagasse biochar promotes microbial growth and metabolism, enhances nutrient $(\mathrm{P}, \mathrm{N}$ and S) cycling, and hence improves soil fertility and quality under metal stress. The promotion of the microbial and biochemical performances in contaminated soils with addition of bagasse biochar is an indicator of improvements in the functioning and quality of the soil due to development of a more active microbial community (Nie et al. 2018; Xu et al. 2018). The improved soil microbial and biochemical indicators under metal stress resulted from biochar application could be attributed to lower metal toxicity, higher soil OC content and addition of labile $\mathrm{C}$ and nutrients (Fig. 1). The RDA analysis in the present study confirmed that OC, DOC and extractable $\mathrm{Cd}$ were dominant factors affecting soil microbial properties (Fig. 4A) while the four soil chemical parameters (OC, DOC and both extractable $\mathrm{Cd}$ and $\mathrm{Pb}$ concentrations) played a major role in enzyme activity. In metalcontaminated soils, application of biochar could reduce the negative effect of metal stress on microbial community with adsorbing free cationic metal ions from the soil solution and 
their toxicity (Park et al. 2011; Yang et al. 2016; Xu et al. 2018). Soil microbial biomass, activity and enzyme activities were increased with the application of bagasse biochar produced at $500{ }^{\circ} \mathrm{C}$ in $\mathrm{Cd}$-polluted soils, which was due to Cd stabilization (Bashir et al. 2018, 2019). Enzyme (urease, catalase and invertase) activities were improved after addition of sugarcane bagasse-derived biochar (produced at $450{ }^{\circ} \mathrm{C}$ ) to a soil contaminated with $\mathrm{Cd}$ and $\mathrm{Pb}$, which was attributed to enhanced heavy metal immobilization following biochar application (Nie et al. 2018). Most soil microbial properties were positively correlated with OC and DOC contents (Table $\mathrm{S} 1$ ), which suggests the added substrate $\mathrm{C}$ by biochar also plays an important role in promoting the microbial communities and thus maintaining their functionalities in metal-contaminated soils, in accordance with the RDA results (Fig. 4). The input of $\mathrm{C}$ compounds from biochar into the soil, especially DOC, is an important driver for stimulating microbial activity and biomass $\mathrm{C}$ immobilization as an immediate source of microbial substrate (Ouyang et al. 2014; Bashir et al. 2018; Song et al. 2019), and for the increased enzyme activity as an enzyme substrate (Khadem and Raiesi 2017; Song et al. 2019). Bashir et al. (2018) found that addition of sugarcane bagasse-derived biochar stimulated URE and DEH activities by increasing microbial biomass in metal co-contaminated soils. Soil amendment with biochar would lessen the unfavorable effects of toxic metals on soil microbial community by providing $\mathrm{C}$ substrates for microbial consumption, making DOC and nutrients available for microbes and enhancing soil water retention and supply to microorganisms (Yang et al. 2016; Huang et al. 2017; Nie et al. 2018; Xu et al. 2018; Bashir et al. 2018, 2019). The ratio of microbial respiration to microbial biomass, also known as the specific respiratory quotient or metabolic quotient $\left(q \mathrm{CO}_{2}\right)$, is often used to demonstrate metal stress in the microbial community (Anderson and Domsch 2010). We observed that the $q \mathrm{CO}_{2}$ was positively correlated with $\mathrm{Pb}$ availability but not with $\mathrm{Cd}$ availability (Table $\mathrm{S} 1$ ), indicating the potential $\mathrm{Pb}$ stress to microbial community. In contrast, we noted that addition of biochar lowered the $q \mathrm{CO}_{2}$ value, which is similar to other studies (Khadem and Raiesi 2017; Liu et al. 2019). This indicates an active microbial community under less stress conditions to produce more enzymes under metal stress conditions when more substrate $\mathrm{C}$ is available for microbial assimilation. This positive impact of the biochar specifically explained the reduction in extractable metal contents in the soils treated with biochar, in particular $\mathrm{Pb}$ availability. The decrease in $q \mathrm{CO}_{2}$ would mean soil microorganisms would metabolize a smaller amount of $\mathrm{C}$ and respire less $\mathrm{CO}_{2}$ per unit microbial biomass per unit time as stress decreases, and a shift of energy and substrate to growth rather than maintenance of the microbial population (Anderson and Domsch 2010; Liu et al. 2019). The negative correlations of enzyme activities with the $q \mathrm{CO}_{2}$ values (Table $\mathrm{S} 1$ ) suggest that the accelerated enzyme activity following biochar application is closely linked to the metal stress and the formation of microbial biomass to synthesize enzymes in contaminated soils.

Our findings confirm that the improvements of soil microbial functions were not only because of the declined metal toxicity and stress as a consequence of their immobilization on bagasse biochar surfaces, but also because of the substrate $\mathrm{C}$ provided by biochar for the metabolically active microorganisms. Redundancy analysis (RDA) results further indicated that better soil microbial conditions and enzyme activities were associated with lower metal availability and higher substrate availability in biochar-treated soils. However, the use of RDA indicated that a large portion of the total variability observed in microbial properties (80\%) and enzyme activities (51\%) was only explained by soil OC (Fig. 4), as is supported by the Pearson correlation results (Table S1). This suggests that soil OC was a major explanatory variable and thus played a major role in the microbial decomposer community and enzyme activity compared with metal immobilization.

Nonetheless, the positive impacts on the measured microbial and biochemical properties were greater with low than high-temperature biochar in accordance with greater volatile matter content in the former (Table 1). This is further supported by higher $\mathrm{C}$ turnover rate of low-temperature biochar $(4.2 \%)$ than that of high-temperature biochar $(3.5 \%)$ observed after 120 days of incubation. The higher atomic $\mathrm{O} / \mathrm{C}$ ratio and lower content of fixed $\mathrm{C}$ in low-temperature biochar (Table 1) also imply an organic amendment with less recalcitrance and low aromaticity. Further evidence is the lower qM value in the B600-amended (1.8\%) than the B400-amended (2.3\%). This indicates that the biochar produced at a high pyrolysis temperature is more resistance to microbial decomposition, in agreement with previous studies (Khadem and Raiesi 2017). Hence, a low-temperature bagasse biochar can support a larger microbial community with more microbial biomass and metabolic activity in the $\mathrm{Cd} / \mathrm{Pb}$ contaminated soils. The strong relationships between soil microbial properties (Table S1) suggest that the higher microbial activity and biomass with the biochar produced at low temperature were accompanied by higher enzyme activities.

In this experiment, the soil microbial population was exposed to metal toxicity resulting from both $\mathrm{Cd}$ and $\mathrm{Pb}$, which may act interactively due to competitive sorption processes (Huang et al. 2017; Xu et al. 2018; Ni et al. 2019; Jiang et al. 2020). In unamended treatments, the co-contamination of soil with $\mathrm{Cd}$ and $\mathrm{Pb}$ reduced microbial and biochemical properties compared with single $\mathrm{Cd}$ or $\mathrm{Pb}$ contamination, which was due to the greater availability of one metal in the presence of the other metal. This suggests that soil co-contamination by $\mathrm{Cd}$ and $\mathrm{Pb}$ might have a greater 
harmful impact on the soil microorganisms. Similarly, earlier reports showed microbial biomass and respiration, and enzyme activity were inhibited more in soil co-spiked with $\mathrm{Cd}$ and $\mathrm{Pb}$ compared with soils spiked with $\mathrm{Cd}$ or $\mathrm{Pb}$ alone (Khan et al. 2010; Huang et al. 2017; Zhan et al. 2018; Xu et al. 2018). Indeed, the great reductions in microbial and biochemical functions under the co-contamination of metals might suggest a synergistic inhibitory effect of $\mathrm{Cd}$ and $\mathrm{Pb}$ when both metals coexist in the soil (Huang et al. 2017). Interestingly, biochar application improved microbial properties and processes in soils co-contaminated with $\mathrm{Cd}$ and $\mathrm{Pb}$, but this positive impact of biochar was often less pronounced in the co-contaminated soils than in single-contaminated soils. This could be attributed to the greater reduction in $\mathrm{Cd}$ availability than in $\mathrm{Pb}$ availability in co-spiked soils amended with biochar under competitive adsorption conditions (Fig. 1). These observations would also confirm the results of metal availability described previously: (1) soil $\mathrm{Cd}$ might impose a synergistic effect on $\mathrm{Pb}$ availability with biochar in the co-presence of heavy metals and (2) the lower efficiency of biochar to reduce the availability of heavy metals (here $\mathrm{Pb}$ ) when $\mathrm{Pb}$ and $\mathrm{Cd}$ coexisted in the soil.

\section{Summary and conclusions}

In support of our first hypothesis, sugarcane bagasse biochar alleviated the negative effect of metal toxicity on microbial and biochemical properties of the soils spiked either separately or jointly with $\mathrm{Cd}$ and $\mathrm{Pb}$. However, the beneficial impacts of biochar were lower in co-contaminated soils than in single-contaminated soils, confirming our second hypothesis. In addition, the positive effect of low-temperature biochar $\left(400^{\circ} \mathrm{C}\right)$ on microbial and biochemical functions was more pronounced than that of high-temperature biochar $\left(600{ }^{\circ} \mathrm{C}\right)$. Biochar addition could lessen the detrimental effect of metals on microbial properties of metal co-contaminated through the supply of the easily available substrates and essential elements as well as metal immobilization. Therefore, it can be concluded that the addition of biochar prepared from sugarcane wastes is a cost-effective remediation method, and promising strategy to restore the co-contaminated soils by reducing metal availability, and improving microbiological and biochemical conditions. However, this study was conducted using an incubation experiment with artificially spiked soils, and large-scale and long-term field experiments using naturally contaminated soils are needed to verify these results.

Supplementary Information The online version contains supplementary material available at https://doi.org/10.1007/s42773-021-00123-0.
Acknowledgements Shahrekord University provided the funding for this research (grant/award number: 97GRN1M1932).

Funding Shahrekord University, grant/award number: 97GRN1M1932.

Data availability The data that support the findings of this study are available from the corresponding author upon request.

\section{Declarations}

Conflict of interest The authors declare that they have no competing interests.

Open Access This article is licensed under a Creative Commons Attribution 4.0 International License, which permits use, sharing, adaptation, distribution and reproduction in any medium or format, as long as you give appropriate credit to the original author(s) and the source, provide a link to the Creative Commons licence, and indicate if changes were made. The images or other third party material in this article are included in the article's Creative Commons licence, unless indicated otherwise in a credit line to the material. If material is not included in the article's Creative Commons licence and your intended use is not permitted by statutory regulation or exceeds the permitted use, you will need to obtain permission directly from the copyright holder. To view a copy of this licence, visit http://creativecommons.org/licenses/by/4.0/.

\section{References}

Abdu N, Abdullahi AA, Abdulkadir A (2017) Heavy metals and soil microbes. Environ Chem Lett 15:65-84

Ahmad M, Rajapaksha AU, Lim JE, Zhang M, Bolan N, Mohan D, Vithanage M, Lee SS, Ok YS (2014) Biochar as a sorbent for contaminant management in soil and water: a review. Chemosphere 99:19-33

Alef K, Nannipieri P (1995) Methods in applied soil microbiology and biochemistry. Academic Press, London

Alloway BJ (2013) Sources of heavy metals and metalloids in soils. In: Alloway BJ (ed) Heavy metals in soils: trace metals and metalloids in soils, and their bioavailability. Springer Science

+ Business Media, Dordrecht, pp 11-50

Anderson TH, Domsch KH (2010) Soil microbial biomass: the ecophysiological approach. Soil Biol Biochem 42:2039-2043

Azeem M, Hayat R, Hussain Q, Tahir MI, Imran M, Abbas Z, Sajid S, Latif A, Irfan M (2019) Biochar improves soil quality and $\mathrm{N}_{2}$-fixation and reduces net ecosystem $\mathrm{CO}_{2}$ exchange in a dryland legume-cereal cropping system. Soil Tillage Res 186:172-182

Bashir S, Hussain Q, Akmal M, Riaz M, Hu H, Ijaz SS, Iqbal M, Abro S, Mehmood S, Ahmad M (2018) Sugarcane bagassederived biochar reduces the cadmium and chromium bioavailability to mash bean and enhances the microbial activity in contaminated soil. J Soils Sediments 18:874-886

Bashir S, Rehman M, Yousaf M, Salam A, Gulshan AB, Iqbal J, Aziz I, Azeem M, Rukh S, Asghar RMA (2019) Comparative efficiency of wheat straw and sugarcane bagasse biochar reduces the cadmium bioavailability to spinach and enhances the microbial activity in contaminated soil. Int J Phytoremediat 21:1098-1103

Bento LR, Castro AJR, Moreira AB, Ferreira OP, Bisinoti MC, Melo CA (2019) Release of nutrients and organic carbon in different soil types from hydrochar obtained using sugarcane bagasse and vinasse. Geoderma 334:24-32 
Bolan N, Kunhikrishnan A, Thangarajan R, Kumpiene J, Parke J, Makino T, Kirkham MB, Scheckel K (2014) Remediation of heavy metal (loid)s contaminated soils-to mobilize or to immobilize? J Hazard Mater 266:141-166

Ding W, Dong X, Ime IM, Gao B, Ma LQ (2014) Pyrolytic temperatures impact lead sorption mechanisms by bagasse biochars. Chemosphere 105:68-74

Fan J, Cai C, Chi H, Reid BJ, Coulon F, Zhang Y, Hou Y (2020) Remediation of cadmium and lead polluted soil using thiolmodified biochar. J Hazard Mater 388:122037

Green VS, Stott DE, Diack M (2006) Assay for fluorescein diacetate hydrolytic activity: optimization for soil samples. Soil Biol Biochem 38:693-701

Gul S, Whalen JK, Thomas BW, Sachdeva V, Deng H (2015) Physico-chemical properties and microbial responses in biocharamended soils: mechanisms and future directions. Agric Ecosyst Environ 206:46-59

Guo LJ, Zhang ZS, Wang DD, Li CF, Cao CG (2015) Effects of short-term conservation management practices on soil organic carbon fractions and microbial community composition under a rice-wheat rotation system. Biol Fertil Soils 51:65-75

Huang S, Jia X, Zhao Y, Bai B, Chang Y (2017) Elevated $\mathrm{CO}_{2}$ benefits the soil microenvironment in the rhizosphere of Robinia pseudoacacia $\mathrm{L}$. seedlings in $\mathrm{Cd}$ - and $\mathrm{Pb}$-contaminated soils. Chemosphere 168:606-616

Inyang M, Gao B, Yao Y, Xue Y, Zimmerman AR, Pullammanappallil P, Cao X (2012) Removal of heavy metals from aqueous solution by biochars derived from anaerobically digested biomass. Bioresour Technol 110:50-56

Jiang L, Yi X, Xu B, Lai K (2020) Effect of wheat straw derived biochar on immobilization of $\mathrm{Cd}$ and $\mathrm{Pb}$ in single- and binary-metal contaminated soil. Hum Ecol Risk Assess 4:1-14

Joergensen RG (1995) Microbial biomass: the fumigation-incubation method. In: Alef K, Nannipieri P (eds) Methods in applied soil microbiology and biochemistry. Academic Press, London, pp 375-381

Khadem A, Raiesi F (2017) Responses of microbial performance and community to corn biochar in calcareous sandy and clayey soils. Appl Soil Ecol 114:16-27

Khan S, Hesham AEL, Qiao M, Rehman S, He JZ (2010) Effects of $\mathrm{Cd}$ and $\mathrm{Pb}$ on soil microbial community structure and activities. Environ Sci Pollut Res 17:288-296

Kozak M, Piepho HP (2018) What is normal anyway? Residual plots are more telling than significance tests when checking ANOVA assumptions. J Agro Crop Sci 204:86-98

Kuperman RG, Siciliano SD, Römbke J, Oorts K (2014) Deriving sitespecific soil clean-up values for metals and metalloids: rationale for including protection of soil microbial processes. Integr Environ Assess Manag 10:388-400

Lehmann J, Rillig MC, Thies J, Masiello CA, Hockaday WC, Crowley D (2011) Biochar effects on soil biota-a review. Soil Biol Biochem 43:1812-1836

Lin Q, Brookes PC (1999) An evaluation of the substrate-induced respiration method. Soil Biol Biochem 31:1969-1983

Lindsay WL, Norvell WA (1978) Development of a DTPA soil test for zinc, iron, manganese, and copper. Soil Sc Soc Am J 42:421-428

Liu J, Xie J, Chu Y, Sun C, Chen C, Wang Q (2008) Combined effect of cypermethrin and copper on catalase activity in soil. J Soils Sediments 5:327-332

Liu Z, Zhu M, Wang J, Liu X, Guo W, Zheng J, Bian R, Wang G, Zhang X, Cheng K, Liu X, Li L, Pan G (2019) The responses of soil organic carbon mineralization and microbial communities to fresh and aged biochar soil amendments. GCB Bioenergy 11:1408-1420
Lu K, Yang X, Gielen G, Bolan N, Ok YS, Niazi NK, Xu S, Yuan G, Chen X, Zhang X (2017) Effect of bamboo and rice straw biochars on the mobility and redistribution of heavy metals $(\mathrm{Cd}, \mathrm{Cu}, \mathrm{Pb}$ and $\mathrm{Zn}$ ) in contaminated soil. Jenviron Manage 186:285-292

Mohamed I, Ali M, Ahmed N, Chen F (2019) Cadmium immobilization and alleviation of its toxicity for soybean grown in a clay loam contaminated soil using sugarcane bagasse-derived biochar. Environ Sci Pollut Res 26:21849-21857

Mohammadi F, Roedl A, Abdoli MA, Amidpour M, Vahidi H (2020) Life cycle assessment (LCA) of the energetic use of bagasse in Iranian sugar industry. Renew Energ 145:1870-1882

Moradi-Choghamarani F, Moosavi AA, Baghernejad M (2019) Determining organo-chemical composition of sugarcane bagassederived biochar as a function of pyrolysis temperature using proximate and Fourier transform infrared analyses. J Therm Anal Calorim 138:331-342

Mukherjee A, Zimmerman AR, Harris W (2011) Surface chemistry variations among a series of laboratory-produced biochars. Geoderma 163:247-255

Nannipieri P, Ascher J, Ceccherini MT, Landi L, Pietramellara G, Renella G (2017) Microbial diversity and soil functions. Eur J Soil Sci 68:12-26

Ni BJ, Huang QS, Wang C, Ni TY, Sun J, Wei W (2019) Competitive adsorption of heavy metals in aqueous solution onto biochar derived from anaerobically digested sludge. Chemosphere 219:351-357

Nie C, Yang X, Niazi NK, Xu X, Wen Y, Rinklebe J, Ok YS, Xu S, Wang H (2018) Impact of sugarcane bagasse-derived biochar on heavy metal availability and microbial activity: a field study. Chemosphere 200:274-282

Ouyang L, Tang Q, Yu L, Zhang R (2014) Effects of amendment of different biochars on soil enzyme activities related to carbon mineralization. Soil Res 52:706-716

Palansooriya KN, Shaheen SM, Chen SS, Tsang DCW, Hashimoto Y, Houg D, Bolanh NS, Rinklebeb J, Oka YS (2020) Soil amendments for immobilization of potentially toxic elements in contaminated soils: a critical review. Environ Int 134:105046

Park JH, Choppala GK, Bolan NS, Chung JW, Chuasavathi T (2011) Biochar reduces the bioavailability and phytotoxicity of heavy metals. Plant Soil 348:439-451

Park JH, Ok YS, Kim SH, Cho JS, Heo JS, Delaune RD, Seo DC (2016) Competitive adsorption of heavy metals onto sesame straw biochar in aqueous solutions. Chemosphere 142:77-83

Pokharel P, Ma Z, Chang SX (2020) Biochar increases soil microbial biomass with changes in extra and intracellular enzyme activities: a global meta-analysis. Biochar 2:65-79

Rahman MA, Jahiruddin M, Kader MA, Islam MR, Solaiman ZM (2021) Sugarcane bagasse biochar increases soil carbon sequestration and yields of maize and groundnut in charland ecosystem. Arch Agron Soil Sci. https://doi.org/10.1080/03650340.2021. 1892651

Raiesi F, Dayani L (2021) Compost application increases the ecological dose values in a non-calcareous agricultural soil contaminated with cadmium. Ecotoxicology 30:17-30

Sarker TC, Azam SMGG, El-Gawad AMA, Gaglione SA, Bonanomi G (2017) Sugarcane bagasse: a potential low-cost biosorbent for the removal of hazardous materials. Clean Techn Environ Policy 19:2343-2362

Shaheen SM, El-Naggar A, Wang J, Hassan NE, Niazi NK, Wang H, Tsang DC, Ok YS, Bolan N, Rinklebe J (2019) Biochar as an (Im) mobilizing agent for the potentially toxic elements in contaminated soils. In: Ok YS, Tsang DCW, Bolan N, Novak JM (eds) Biochar from biomass and waste. Elsevier, Amsterdam, pp 255-274 
Smolders E, Mertens J (2013) Cadmium. In: Alloway BJ (ed) Heavy metals in soils: trace metals and metalloids in soils, and their bioavailability. Springer Science + Business Media, Dordrecht, pp 283-311

Song D, Xi X, Zheng Q, Liang G, Zhou W, Wang X (2019) Soil nutrient and microbial activity responses to two years after maize straw biochar application in a calcareous soil. Ecotox Environ Safe 180:348-356

Spokas KA (2010) Review of the stability of biochar in soils: predictability of O:C molar ratios. Carbon Manag 1:289-303

Steinnes E (2013) Lead. In: Alloway BJ (ed) Heavy metals in soils: trace metals and metalloids in soils, and their bioavailability. Springer Science + Business Media, Dordrecht, pp 395-409

Vig K, Megharaj M, Sethunathan N, Naidu R (2003) Bioavailability and toxicity of cadmium to microorganisms and their activities in soil: a review. Adv Environ Res 8:121-135

Wang Y, Liu Y, Zhan W, Zheng K, Wang J, Zhang C, Chen R (2020) Stabilization of heavy metal-contaminated soils by biochar: challenges and recommendations. Sci Total Environ 729:139060

Xu Y, Seshadri B, Sarkar B, Wang H, Rumpel C, Sparks D, Farrell M, Hall T, Yang X, Bolan N (2018) Biochar modulates heavy metal toxicity and improves microbial carbon use efficiency in soil. Sci Total Environ 621:148-159

Xu Y, Seshadri B, Bolan N, Sarkar B, Ok YS, Zhang W, Rumpel C, Sparks D, Farrell M, Hall T, Dong Z (2019) Microbial functional diversity and carbon use feedback in soils as affected by heavy metals. Environ Int 125:478-488

Yang X, Liu J, McGrouther K, Huang H, Lu K, Guo X, He L, Lin X, Che L, Ye Z, Wang H (2016) Effect of biochar on the extractability of heavy metals $(\mathrm{Cd}, \mathrm{Cu}, \mathrm{Pb}$, and $\mathrm{Zn})$ and enzyme activity in soil. Environ Sci Pollut Res 23:974-984

Yuan P, Wang J, Pan Y, Shen B, Wu C (2019) Review of biochar for the management of contaminated soil: preparation, application and prospect. Sci Total Environ 659:473-490

Zafar-ul-Hye M, Wasim MM, Munir TM, Aon M, Shaaban M, Abbas M, Hussain M, Ahmad M (2020) Co-application of sugarcane bagasse biochar, farmyard manure and mineral nitrogen improved growth indices of corn grown in alkaline calcareous soil. J Plant Nutr 43:1293-1305

Zahedifar M, Moosavi AA (2020) Assessing cadmium availability of contaminated saline-sodic soils as influenced by biochar using the adsorption isotherm models. Arch Agron Soil Sci 66:1735-1752

Zhan J, Li T, Zhang X, Yu H, Zhao L (2018) Rhizosphere characteristics of phytostabilizer Athyrium wardii (Hook.) involved in $\mathrm{Cd}$ and $\mathrm{Pb}$ accumulation. Ecotox Environ Safe 148:892-900

Zhang L, Jing Y, Xiang Y, Zhang R, Luc H (2018) Responses of soil microbial community structure changes and activities to biochar addition: a meta-analysis. Sci Total Environ 643:926-935 